\title{
ПРАВОЗАХИСНИЙ АКТИВІЗМ У ДІЯЛЬНОСТІ ПОЛЬСЬКИХ НЕУРЯДОВИХ ОРГАНІЗАЦІЙ
}

\begin{abstract}
Стаття присвячена дослідженню діяльності польських неурядових організачій у сфері охорони прав людини. Загалом польський «третій сектор» виступає своєрідним каталізатором та важливим фактором у прочесі розбудови громадянського суспільства в краӥні, щзо особливо простежується після 1989 р. із падінням комуністичного режсиу. Саме неурядові організаиії надають істотну підтримку населенню практично в усіх сферах життєдіяльності, правовий захист зокрема. Наведено приклади вже реалізованого позитивного досвіду такої діяльності. Зокрема, охарактеризовано діяльність найбільш авторитетних і досвідчених польських неурядових організачій - Польського Червоного Хреста, Гельсінської фундації з прав людини, Польської Міжнародноі амністії, Карітас тощзо. Вище перераховані НУО є найбільшими із найтириим спектром правозахисноїдіяльності. У Польщі також існують інші організащії. Усі вони однаково важливі та сприяють просуванню ідеї прав людини. Правозахисний активізм неурядових організацій та його форми й масштаби залежать від низки чинників. Це політична структура суспільства, історичні традиції, рівень знання та розуміння громадянами своїх прав, рівень розвитку системи захисту прав людини, фінансування діяльності організацій. Усі цุі фактори тією чи іншою мірою є важливими у прочесі реалізаиії правозахисної діяльності НУО. У досліджуваний період спостерігаємо консолідацію правозахисних неурядових організацій, перетворення їх на активний соціально-політичний фактор у країні. Досвід Польщі, де такі організації свого часу стали ядром у боротьбі за демократичні перетворення, дедалі більше запозичується неурядовими організачіями інших країн, зокрема і Україною, оскільки дотримання прав людини є важливою частиною загального прагнення до демократії, законності та правової держави.
\end{abstract}

Ключові слова: неурядова організачія, права людини, громадянське суспільство, соиіальна допомога.

\section{Bezzubenko Alina. Human rights activism in the activities of Polish non-governmental organizations}

The article is devoted to the study of the activities of Polish non-governmental organizations in the field of human rights protection. In general, the Polish "third sector" acts as a kind of catalyst and an important factor in the process of building civil society in the country, which is especially evident after 1989 with the fall of the communist regime. It is non-governmental organizations that provide significant support to the population in almost all spheres of life, and legal protection in particular. Examples of already realized positive experience of such activity are given. In particular, the activities of the most authoritative and experienced Polish non-governmental organizations are described-the Polish Red Cross, the Helsinki Foundation for Human Rights, Polish Amnesty International, Caritas, etc. The above NGOs are the largest with the widest range of human rights activities. There are also other organizations in Poland. They are all equally important and promote the idea of human rights. Human rights activism of non-governmental organizations and its forms and scale depend on a number of factors. This includes the political structure of society, historical traditions, the level of knowledge and understanding of citizens of their rights, the level of development of the human rights protection system, financing the activities of organizations. All these factors are to some extent important in the process of implementing human rights activities of NGOs. In the period under study, we see the consolidation of human rights NGOs, their transformation into an active socio-political factor in the country. The experience of Poland, where such an organization once became the core of the struggle for democratic transformation, is increasingly being borrowed by non-governmental organizations in other countries, including Ukraine. Due to the fact that human rights are an important part of the general desire for democracy, the rule of law.

Key words: non-governmental organization, human rights, civil society, social assistance.

Нині неурядові організації (далі - НУО) стали постійним елементом польської дійсності. Організації почали виникати в Польщі одночасно з країнами Західної Європи. Однак їхня діяльність у другій половині XX ст. була заборонена, як і в інших країнах соціалістичного табору. Відродження діяльності польського «третього сектора» розпочалося з 1989 р. із падінням комуністичного режиму, оскільки 
саме $з$ цього часу розпочинається процес системної трансформації в країні, а отже, і певні зміни у свідомості та менталітеті польських громадян.

Початок 1990-х рр. був періодом високої динаміки у створенні нових неурядових організацій. Сфера діяльності польських НУО охоплювала практично усі галузі життя громадян - економіку, політику, науку, культуру, освіту, право тощо. 1990-2000-і рр. принесли багато позитивних змін у функціонуванні польського «третього сектора». Серед них варто зазначити професіоналізацію діяльності, активізацію співпраці з офіційною владою та бізнесом, прийняття Закону про громадську діяльність та волонтерську роботу від 24 квітня 2003 р.

Громадські організації в країні мають багатовікову історію, витоки якої можна прослідкувати ще в попередні століття, коли виникали товариства, що брали на себе завдання, які не виконувала держава. Наприклад, вони допомагали бідним, інвалідам, соціально незахищеним верствам суспільства тощо. Зокрема, таку діяльність здійснювали церкви та благодійні товариства.

Тому незалежні організації постійно були присутніми в суспільному житті Польщі і до кінця 1940-х рр. становили важливий елемент соціальної інфраструктури країни. Варто зазначити, що на межі 1940-1950-х рр. такі польські організації, як Польський Червоний Хрест або Карітас, активно діяли у сфері не тільки соціальних послуг, а й у сфері охорони прав людини [1, s. 137-138].

Правозахисний активізм неурядових організацій та його форми й масштаби залежать від низки чинників. Це і політична структура суспільства, історичні традиції, рівень знання та розуміння громадянами своїх прав, рівень розвитку системи захисту прав людини, фінансування. Усі ці фактори тією чи іншою мірою є важливими у правозахисній діяльності НУО. Однак головним, на нашу думку, є ступінь залежності від політичної структури суспільства.

Наприклад, у комуністичний період функціонування незалежних організацій було різко обмежене і піддавалося суворому політичному та адміністративному контролю. Як наслідок, організації, що існували в Польщі у післявоєнний період, були переважно проурядовими установами. Тому цей період характеризується відсутністю політичної, правової та фінансової спроможності для справді незалежних громадських ініціатив, зокрема у сфері захисту прав людини. Основною функцією цих організацій була політична мобілізація, а надання соціальних послуг та захист інтересів різних груп населення стали другорядними. Цей парадокс дав змогу комуністичним урядам офіційно підтримувати громадянські ініціативи, здійснюючи повний контроль над ними [1, s. 138]. На думку М. Новосельського, роки комуністичного правління в Польщі означали дефіцит основних ресурсів, необхідних для вільної діяльності громадянського суспільства та неурядових організацій. Соціальна робота була пов'язана із зобов'язаннями перед державою, самі ж громадяни 3 недовірою ставилися до різних типів громадських об'єднань [2, s. 8].

Визнання прав і свобод людини найвищою цінністю цивілізованого суспільства стало важливим етапом на шляху формування польської держави як демократичної, правової, соціально орієнтованої країни. Так, у 1991 р. Польща стала членом Ради Свропи, у 1993 р. підписала Свропейську конвенцію з прав людини. У Конституції Республіки Польща, яка набрала чинності 17 жовтня 1997 р., положення про «Свободи, права та обов'язки людини і громадянина» містяться у II розділі. Для збереження прав польських громадян створено низку інституцій, таких як Конституційний трибунал, Державний трибунал та Омбудсмен. Тим не менше, як і в більшості демократичних країн, вагому роботу в боротьбі за дотримання стандартів прав людини проводять саме неурядові організації.

Нині в Польщі діє значна кількість різноманітних НУО, що працюють у сфері захисту прав людини. Причому неурядові організації, які намагаються охопити увесь спектр правових питань, становлять конкретні групи тиску та відіграють вагому роль у захисті прав людини не тільки у Польщі, а й в багатьох країнах світу. Завдяки динамічному розвитку НУО після 1989 р. нині вони сприймаються як один iз важливих недержавних суб'єктів у досліджуваній сфері. На думку М. і Дж. Симонідес, діяльність НУО є найкращим прикладом універсалізму прав людини [3, s. 9].

Важливим джерелом інформації про ситуацію в польській державі у сфері охорони прав людини є звіти та соціальні кампанії таких міжнародних організацій, як Amnesty International (Mіжнародна Амністія) чи Human Rights Watch. Серед польських НУО можемо виділити Helsińskiej Fundacji Praw Człowieka (Гельсінська фундація з прав людини), Polski Czerwony Krzyż, PCK (Польський Червоний Хрест), Polska Akcja Humanitarna (Польська Гуманітарна Акція), Caritas тощо.

Однією $з$ перших організацій, що ініціювала правозахисний активізм у країні, можна вважати Polski Czerwony Krzyż, PCK (Польський Червоний Хрест). Це також найстаріша неурядова організація в Польщі, що започаткувала свою діяльність ще у 1919 р. Польський Червоний Хрест орієнтований на поширення ідей гуманізму, готує майбутніх фельдшерів та волонтерів, організовує різноманітні курси, наприклад, курси порятунку, шукає людей, які зникли під час проведення бойових дій, здійснює профілактику інфекційних захворювань та поширення епідемій. 
Мінливі політичні та складні соціально-економічні умови, що настали в країні після 1989 р., значно вплинули на діяльність Польського Червоного Хреста. Особливо гостро постало питання щодо фінансування діяльності організації. У ситуації економічної кризи держава не мала змоги фінансувати такі організації, а спонсорська допомога тільки зменшувалась. У цей період Польський Червоний Хрест зосередив свою увагу на інших формах надання соціальної допомоги. Популярними стали пункти видачі їжі, одягу, ліків тощо. Діяли цілодобові центри догляду для людей похилого віку, людей з обмеженими можливостями, матерів із дітьми, нічні притулки, їдальні. Витрати на утримання цих установ покривались за рахунок різних ресурсів: повітові центри допомоги, центри соціального забезпечення, органи місцевого самоврядування, власні ресурси, кошти інших фундацій і т.д.

Значним досягненням ПЧХ протягом 1989-2003 рр. стала організація мережі центральних інтервенційних складів (у Слупську, Катовіце, Згежі і ін.) та 49 інтервенційних воєводських складів. Польський Червоний Хрест організував відповідну підготовку для працівників та волонтерів щодо організації допомоги жертвам катастроф або стихійних лих (курси, самоосвітні матеріали) [4, s. 124-125].

Особливою формою діяльності організації стала допомога, що надавалась біженцям різних національностей, які перебували на території польської держави. Зокрема, допомога надавалась біженцям із Близького Сходу та Африки, громадянам колишнього Радянського Союзу, циганам із Румунії, громадянам Югославії. 3 початком 1990-х рр. Польський Червоний Хрест брав активну участь в операціях із міжнародної допомоги. Наприклад, тільки у 1989-1991рр. було відправлено 201 транспорт вагою близько 1511 т до місцевих організацій Румунії, Албанії, Ірану, Перу, Болгарії, Сербії, Туреччини, Литви та інших республік колишнього СРСР, Китаю і Югославії [5].

Вагомою організацією у сфері популяризації та охорони прав людини стала Польська Міжнародна амністія, що започаткувала свою діяльність у 1990 р. Вже як 30 років члени організації проводять правозахисні кампанії та освітні проєкти з прав людини. Вони також є творцями найбільшої акції у світі «Maraton pisania listów» («Марафон написання листів»).

31991 р. організація бере активну участь у міжнародних заходах, спрямованих на захист прав людини. Нині вона діє через мережу, ії центри базуються у великих містах (Варшава, Гданськ, Краків, Торунь, Люблін). Ця НУО організовує заходи з популяризації прав людини, проводить кампанії на допомогу ув'язненим із підвищення обізнаності про порушення прав людини, освітні кампанії. Польська Міжнародна амністія проводить кампанії, що торкаються актуальних проблем у сфері захисту людських прав: вимога скасування смертної кари, запобігання насильству щодо жінок та запровадження загального контролю над озброєнням, проведення освітніх проєктів у школах для протидії дискримінації і булінгу тощо.

Зокрема, перша офіційна акція Міжнародної амністії в Польщі відбулася 1990 р., у річницю подій на площі Тяньаньмень. Присутні учасники акції перед посольством КНР вимагали свободи для ув'язнених китайських студентів. Іншим прикладом стала кампанія «Свобода для Білорусі», започаткована у 2005 р. як протести проти обмеження свободи слова в цій країні. Сотні поляків та білорусів, які проживали в Польщі, запалили «свічки солідарності» на вулицях польських міст - у Білостоці, Гдині, Кракові, Лодзі, Познані, Варшаві та Вроцлаві. У столиці акція зібрала близько 70 учасників, які, тримаючи свічки в руках, утворили живий ланцюг на вулиці Нови Свят.

У 2001 р. активісти організації започаткували марафон написання листів, що $є$ найбільшою подією 3 прав людини у світі. Відтоді щороку на захист потерпілих людей пишеться тисяча листів. Наприклад, у 2019 р. таких листів було 6500. Найважливішою метою марафону написання листів є бажання вплинути на долю людей, чиї права порушуються. Як стверджують члени організації, листи дійсно $\epsilon$ ефективними. Багато людей, які беруть участь у марафоні, отримують відповіді на свої листи, i ті, кого звільнили завдяки цим листам, зізнаються, що листи заохочували їх та втішали у важкі часи. Листи солідарності стали великою підтримкою для переслідуваних та ув'язнених.

Діяльність Гельсінської фундації з прав людини у Польщі бере свій початок у 1982 р. Тоді ця організація була відома як Гельсінський комітет і ії робота велася лише підпільно. Після зміни режиму в 1989 р. Комітет перетворився на Фундацію. Він виходить із підпілля, стає незалежною неурядовою організацією з питань освіти та досліджень прав людини. У такій формі Фундація функціонує дотепер.

У 1980-х рр. основна діяльність Комітету полягала в пошуку інформації щодо правового становища поляків та оприлюднення інформації щодо порушення їхніх прав. Результатом роботи стали звіти «Польща під час воєнного стану» та «Права людини та громадянина в Народній Республіці Польща», представлені на конференції з питань безпеки та співробітництва в Свропі в Мадриді.

На початку 1990-х рр. Гельсінська фундація з прав людини створила першу Програму правової допомоги біженцям та мігрантам. Юристи неурядової організації надають безплатну юридичну 
консультацію іноземцям, які звертаються до Фундації. Ще однією програмою стала Клініка невинуватості - в рамках своєї роботи адвокати Гельсінської фундації з прав людини розшукують помилки, допущені на будь-якій стадії кримінального провадження, які могли призвести до несправедливого засудження.

Основними видами діяльності є моніторинг, наприклад, законодавчих процесів, а також освітніх та інших ініціатив у цій галузі. Експерти Гельсінської фундації з прав людини підготували численні журналістські програми, тренінги, семінари та конференції з правозахисної тематики. Цікавою ініціативою та освітньою складовою частиною діяльності фундації є також організація Міжнародної літньої школи з прав людини, яка проводиться щороку з 1990 р. Ця програма адресована неурядовим організаціям, журналістам та державним службовцям, які спеціалізуються на захисті прав людини в постсоціалістичних країнах Центральної та Східної Свропи, а також Середньої Азії.

Нині Гельсінська фундація з прав людини є однією з найбільш досвідчених і професійних неурядових організацій у сфері прав людини не тільки в Польщі, а й в Європі. 32007 р. вона має консультативний статус при Економічній і Соціальній Раді OOH (ECOSOC).

Перераховані вище НУО є найбільшими з найширшим спектром діяльності. У Польщі також існують такі організації, як SOS Foundation, Caritas Polska та Польська гуманітарна акція. Всі вони однаково важливі і сприяють просуванню ідеї прав людини.

Польські неурядові організації відіграють важливу роль у наданні соціальної допомоги. 3 моменту відновлення в 1990 р. піклується про безпритульних, хворих, інвалідів, людей похилого віку, сиріт, дітей із бідних сімей, багатодітні сім'ї, а також мігрантів та біженців Caritas Polska. Організація створила багато професійних та освітніх установ, пункти догляду, реабілітаційні центри, будинки соціальної допомоги, майстерні трудотерапії, будинки для матерів-одиначок, їдальні для бідних тощо.

У досліджуваний період Caritas Polska ініціювала проведення низки важливих соціальних заходів. Однією з перших в 1994 р. постала соціальна кампанія «Wigilijne Dzieło Pomocy Dzieciom» («Різдвяна робота на допомогу дітям»). Кампанія полягала в роздачі свічок у парафіях по всій країні, які напередодні Різдва запалюють на своїх столах поляки на знак солідарності з найбільш нужденними у Польщі та світі. Кошти, отримані під час проведення цієї кампанії, призначені для харчування, освітньої допомоги та літнього відпочинку для тисяч дітей із сімей, які потребують підтримки [6, s. 326-327].

Важливою ініціативою Caritas Polska стала «Wakacyjna Akcja Caritas» («Святкова акція Карітас»), завдяки якій щороку близько 200 дітей із бідних сімей мають змогу відпочити безплатно в літніх таборах. Діти можуть поліпшити своє здоров'я, сформувати навички правильної поведінки. Це також прекрасна нагода відсторонитись від тих проблем, з якими вони, на жаль, стикаються щодня. Іноді табори Карітас є єдино можливою формою відпочинку для цих дітей. Перебування в літніх таборах включає екскурсійні поїздки, відвідування місцевих туристичних визначних пам'яток, а також низку заходів, спрямованих на всебічний розвиток дитини.

Протягом кількох років із нагоди Дня дітей влаштовуються загальнонаціональні сімейні гуляння під гаслом «Будьмо разом». Основною метою акції є привернення уваги до цінностей, які приносить саме родина. Кошти, зібрані під час фестивалів, призначені на лікування дітей. Наприклад, тільки у 2011 p. такі фестивалі проводились у 19 польських містах [6, s. 327].

Caritas Polska надає допомогу і жертвам воєн, стихійних лих за межами Польщі, в Африці, Азії, Латинській Америці та Європі. Ця НУО заснувала відповідні Центри допомоги, які працюють донині. Першим стимулом до створення таких центрів став наплив чеченського народу внаслідок конфлікту на Кавказі, а також босняків та сербів після війни в колишній Югославії в 1990-х рр. 3 січня 2016 р. Caritas спільно із шістьма місцевими Центрами допомоги мігрантам та біженцям реалізовує проєкт «Nowy Dom Polska». Він включає надання соціальної або психологічної допомоги, фінансової допомоги для оренди житла чи сплати за дитячий садок, придбання підручників, шкільного приладдя, ліків, за незначні медичні процедури. За підрахунками протягом 2016-2017 рр. послугами Центру скористалося близько 5 тис. осіб [7, s. 5-6]. Caritas керує п’ятьма центрами допомоги мігрантам та біженцям у Польщі, в яких щороку надає допомогу понад 3 тис. людей. Орієнтовний розмір наданої допомоги у 2015 р. становив майже 12 млн злотих [7, s. 6].

У грудні 2015 p. Caritas Polska реалізувала проєкт допомоги внутрішнім біженцям в Україні, у зв'язку 3 конфліктом на сході нашої країни. Гуманітарне відправлення з пожертвами (продукти харчування та гігієни, зимовий одяг, спальники та обігрівачі) було надіслано до Харкова і Запоріжжя.

Таким чином, польські правозахисні НУО відіграють важливу роль у сфері охорони прав людини в країні. У досліджуваний нами період спостерігаємо консолідацію правозахисних неурядових організацій, перетворення їх на активний соціально-політичний фактор. Досвід Польщі, де такі НУО свого 
часу стали ядром у боротьбі за демократичні перетворення, дедалі більше запозичується неурядовими організаціями інших країн, зокрема Україною чи Білоруссю, оскільки дотримання прав людини є важливою частиною загального прагнення до демократії, законності та правової держави.

Однак дати однозначну відповідь щодо визначення ефективності діяльності польських НУО у сфері захисту прав людини досить важко. Оскільки їхня робота не позбавлена певних помилок та недоліків. Іноді в їхніх діях, на думку громадськості, прослідковується проведення спеціально видовищних акцій із метою набуття публічності, участь у політиці, незважаючи на заяву про аполітичність, і т.д. Проте вони, безумовно, впливають на поведінку та політику держави. Польські НУО закликають уряд брати участь у певних діях та утримуватися від дій, що порушують права людини. Вони також звертають увагу уряду та міжнародних організацій на найбільш значущі проблеми у сфері охорони прав людини, що прослідковуються в країні.

\section{Література:}

1. Organizacje pozarządowe w społeczeństwie obywatelskim / Pod red. Małgorzaty Załuskiej i Jerzego Boczonia. Katowice: Śląsk, 1998. $178 \mathrm{~s}$.

2. Nowosielski M. Odradzanie się społeczeństwa obywatelskiego. Rozwój polskiego trzeciego sektora w latach 1989-2008. Poznań : Instytut Zachodni, 2008-2009. 64 s.

3. Symonides M., Symonides J. Wkład organizacji pozarządowych w promocję i ochronę praw człowieka. Stosunki Międzynarodowe. 2004. Nr 1-2. S. 9-24.

4. Cichocka M.Ł. Polski Czerwony Krzyż w latach 1919-2004. Płock : Wyd. Naukowe Novum, 2006. $171 \mathrm{~s}$.

5. Historia PCK. Działalność po roku 1989. URL: http://pck.malopolska.pl/kim-jestesmy/\#1509706391599-b341afad-3388

6. Działalność organizacji pozarządowych - 10 lat Doświadczeń: pod rządami ustawy o działalności pożytku publicznego i wolontariacie / Red. nauk.: Monika Falej, Piotr Majer, Urszula Szymańska. Olsztyn, 2015. 392 s.

7. Organizacje pozarządowe zajmujące się pomocą dla uchodźców i migrantów. Opracowania tematyczne. OT-650. Kancelaria Senatu. Styczeń 2017. URL: https://www.senat.gov.pl/gfx/senat/pl/senatopracowania/146/plik/ot-650_internet.pdf

8. Беззубенко А.В. Хельсінкський фонд з прав людини в Польщі (1989-2004рр.). Збірник наукових пращь Харківського наиіонального педагогічного університету імені Г.С. Сковороди. Сер.: Історія та географія. 2012. № 44. С. 108-110.

9. Historia a prawa człoweka. Warszawa : Ośrodek KARTA, 2013. $212 \mathrm{s.}$ 